\title{
Forest Protection through Sasi: Local Environmental Law in Ambon Island Post COVID -19 Pandemic
}

\author{
Aarce Tehupeiory ${ }^{1}$, Haposan Sahala Raja Sinaga ${ }^{2}$, Lamhot Naibaho ${ }^{3}$
}

1Postgraduate Program, Universitas Kristen Indonesia, E-mail: aartjetehupeiory@gmail.com 2Faculty of Law, Universitas Kristen Indonesia, E-mail: haposan.sinaga@uki.ac.id ${ }^{3}$ Faculty of Letter and Languages, Universitas Kristen Indonesia, E-mail: lamhot.naibaho@uki.ac.id

\begin{tabular}{l}
\hline Info Article \\
\hline Received:10th August 2021 \\
Accepted: $28^{\text {th }}$ September 2021 \\
Published:30th September 2021 \\
Keywords: \\
Forest Protection; Local \\
Environmental Law; Sasi \\
Corresponding Author: \\
Lamhot Naibaho, E-mail: \\
lamhot.naibaho@uki.ac.id \\
DOI: \\
10.24843/IMHU.2021.v10.i03.p05 \\
\end{tabular}

\begin{tabular}{l} 
Abstract \\
\hline This study discusses forest protection through Sasi (Local \\
Environmental Law) in Ambon island post-COVID-19. Sasi is a \\
customary norm and rules and sanctions regarding the \\
prohibition of taking plant or plant products, fish and game time \\
before the time agreed and determined by community leaders and \\
leaders together with community members. The main goal is to \\
conserve natural resources, control and limit human greed in \\
overexploiting natural resources. The research method used is a \\
qualitative research method with normative legal research. The \\
research was conducted at Universitas Kristen Indonesia from \\
January to March 2021. The objects studied were documents \\
either in reports or regulations related to indigenous peoples' \\
local wisdom. The research instrument used was a document \\
checklist. The data analysis technique used is the descriptive \\
analysis tednnique. The researdh results are that traditional Sasi \\
wisdom has values and norms to protect forests, water sources, \\
annual plants, and food plants. With the concept and \\
understanding of how environmental managements with various \\
customary rules to obtain benefits and maintain the kinship \\
value of area units that already have an identity and must \\
continuously be maintained in the aftermath of the COVID-19 \\
pandemic.
\end{tabular}

\section{Introduction}

One of the factors "that caused the failure of positive laws in forest protection was eliminating taboos and prohibitions on forests that indigenous communities had practised for centuries as part of local forestry law content. In addition, residents around the forest are less involved in maintaining the surrounding forest, which should be they are the ones who move quickly and report every act of forest destruction that occurs in their area". ${ }^{1}$ However, "because the prevailing forest protection law system alienates people around the forest, people tend to ignore forest encroachment cases, even though they are aware of it. The village community

\footnotetext{
${ }^{1}$ William D Sunderlin et al., "Livelihoods, Forests, and Conservation in Developing Countries: An Overview," World Development 33, no. 9 (2005): 1383-1402.
} 
considers the responsibility for forest protection under the authority of the forestry police apparatus". ${ }^{2}$

Earth, water and natural resources contained therein are controlled by the state and used as much as possible for the people's prosperity. Natural resources are elements of the environment consisting of biological and non-living resources that form a unitary ecosystem. ${ }^{3}$ Then Article "1 point, 16 states that what is meant by environmental destruction is an act of a person causing direct or indirect changes to the physical, chemical and biological characteristics of the environment so that it exceeds the standard criteria for environmental damage".4

Provisions regulating "the conservation of living natural resources and ecosystems existed for Indonesia in the laws and regulations in the colonial era. The statutory regulations are dierenbeschermings Ordonantie 1931 stb. 1931 No 134, Jacht Ordonantie 1931 stb. 1931 no.133, Jacht Ordonantie Java and Madura 1940 stb. 1939 No.733 and Natuurbeseschermings Ordonantie 1941 stb. 1941 no.167".5 In the era of Indonesian independence, "laws and regulations on the conservation of living natural resources and ecosystems can be seen in Law no. 5 of 1990 concerning Conservation of Natural Resources and their Ecosystems, Law no. 5 of 1997 concerning Basic Forestry Provisions, and most recently regulated in Law no. 32 of 2009 concerning Protection and Management of the Environment".6

"Law No. 32 of 2009 provides an understanding of local wisdom, namely the noble values that apply in the order of community life to, among others, protect and manage the environment in a sustainable manner. Natural resources were created to be utilized by humans. Still, there are rules and limitations to maintain the balance of nature".? These limitations include principles in conservation, which limit human behaviour to utilize natural resources wisely. People in Ambon island do not recognize the term "conservation", even though the meaning contained in the term conservation lives in their activities as farmers. There are wisdom values in utilizing natural resources. These values align with the concept of "conservation" so that the natural resources they depend on for their survival will not run out and become extinct. 8

The condition of the forest, which is "increasingly damaged due to encroachment by irresponsible people, is evidence of the lack of cooperation between the government and the customary law community. Therefore, sustainable and equitable forestry

2 Tanya Hayes and Elinor Ostrom, "Conserving the World's Forests: Are Protected Areas the Only Way," Ind. L. Rev. 38 (2005): 595.

${ }^{3}$ John M Balbus et al., "Implications of Global Climate Change for the Assessment and Management of Human Health Risks of Chemicals in the Natural Environment," Environmental Toxicology and Chemistry 32, no. 1 (2013): 62-78.

4 Alan Boyle, "Human Rights or Environmental Rights? A Reassessment," Fordham Environmental Law Review, 2007, 471-511.

${ }^{5}$ Siti Sundari Rangkuti, Hukum Lingkungan \& Kebijaksanaan Ling Nasional Ed 4 (Airlangga University Press, 2020).

${ }^{6}$ Timo Kuuluvainen, "Forest Management and Biodiversity Conservation Based on Natural Ecosystem Dynamics in Northern Europe: The Complexity Challenge," Ambio, 2009, 309-15.

7 Umi Muawanah et al., "Review of National Laws and Regulation in Indonesia in Relation to an Ecosystem Approach to Fisheries Management," Marine Policy 91 (2018):150-60.

8 Sven Erik Jørgensen et al., Flourishing Within Limits to Growth: Following Nature's Way (Routledge, 2015). 
development can be achieved if there is a paradigm shift".9 "The new paradigm of forestry development is a shift in orientation from forest management to resourcebased management, centralized management to decentralized, and more equitable resource management. For this reason, customary law communities living around the forest need to be involved as mandated by law".10

In the era of regional autonomy, it is worth considering efforts to revitalize the participation of customary law communities in managing, maintaining, directing the pattern of forest protection regulations by adopting local law values that had been in effect during the pre-state law (state law). Opportunity to re-enforce local legal rules constitutionally has a foothold based on the 1945 Constitution of the Republic of Indonesia Article 18 B paragraph (2) which states that "The State recognizes and respects indigenous peoples and their traditional rights as long as they are alive. and following the development of society and the principles of the Unitary State of the Republic of Indonesia, which are regulated in law".11

In addition, "the operational juridical recognition of customary law communities has a legal basis in Law Number 5 of 1960 concerning Basic Agrarian Principles. Article 3, in essence, determines" "... the exercise of customary rights and similar rights from customary law communities, as long as they still exist, it must be in such a way that it is in line with the national and state interests ...".12 In addition, "Law Number 41, the Year 1999 concerning Forestry in Article 67 also recognizes customary law communities. The recognition of the existence of customary law communities is also strengthened in Law Number 32 of 2004 concerning Regional Government in Article 2 paragraph (9), which stipulates that the state recognizes and respects indigenous peoples and their traditional rights as long as they are still alive and following the development of society and the principles of the Unitary State of the Republic of Indonesia".13

Humans and natural resources cannot be separated, and they are one unit. At the beginning of the creation of the universe, God equipped humans with the universe and everything that humans need, land and sea with everything in it, the sun, moon and stars that provide energy and lighting for humans. Therefore, humans are obliged to protect their environment, maintain and preserve it because everything is intended for humans to be used wisely. ${ }^{14,15}$ When humans have not been tempted by worldly

9 John A Wiens, "Landscape Ecology as a Foundation for Sustainable Conservation," Landscape Ecology 24, no. 8 (2009): 1053-65.

${ }^{10}$ Peter Cronkleton, David Barton Bray, and Gabriel Medina, "Community Forest Management and the Emergence of Multi-Scale Governance Institutions: Lessons for REDD+ Development from Mexico, Brazil and Bolivia," Forests 2, no. 2 (2011): 451-73.

11 Aarce Tehupeiory, "SASI-BASED PROTECTION FOREST STRATEGY IN MALUKU (AMBON)," International Journal of Research-GRANTHAALAYAH 9, no. 3 (2021):221-28.

${ }^{12}$ Herman Hidayat et al., "Forests, Law and Customary Rights in Indonesia: Implications of a Decision of the Indonesian Constitutional Court in 2012," Asia Pacific Viewpoint 59, no. 3 (2018): 293-308.

${ }^{13}$ Siegfried Wiessner, "Indigenous Sovereignty: A Reassessment in Light of the UN Declaration on the Rights of Indigenous People," Vand. J. Transnat'l L. 41 (2008): 1141.

${ }^{14} \mathrm{R}$ Warren Flint, Practice of Sustainable Community Development: A Participatory Framework for Change (Springer, 2012).

15 Jame Schaefer, Theological Foundations for Environmental Ethics: Reconstructing Patristic and Medieval Concepts (Georgetown University Press, 2009). 
consumerism, which can be seen in traditional rural communities, there will be pretty wise values related to natural resources. In every agrarian society throughout Indonesia, there is "wisdom" in interacting with nature. Initially, in a 'magical religious' understanding, it later becomes an attachment that nature has given life so that it needs to be preserved and preserved.

Coronavirus Disease-19, abbreviated as COVID-19, has had a broad impact on human life globally, impacting the health sector and the socio-economic sector. The World Health Organization (WHO) declared COVID-19 as a Global Pandemic on March 11, 2020, while the Government of Indonesia had just declared COVID-19 as a pandemic or non-natural national disaster through Presidential Decree No. 12 of 2020. The stipulation of COVID-19 as a pandemic or National disaster has implications for community social activities. The goal is to overcome or break the chain of the spread of COVID-19. Still, the existence of community social activities turns out to significantly impact the community itself. The number of community social activities that disrupt the economy, there are no people in Ambon island, Maluku. Therefore, dealing with the COVID-19 pandemic situation, the Sasi law in Ambon island can also be used as an instrument to transmit the virus from human to human.

Concerning the "information above, the implementation of forest protection must be increased immediately. One way that can be done in Ambon island post-COVID-19 is by implementing the Sasi policy".16 "Sasi is traditional wisdom with values and norms to protect forests, water sources, annual plants (sago), food crops, nutmeg plants, and hundreds of years old or forest trees. Therefore, researchers are very interested in studying forest protection based on Sasi".

\section{Research Method}

This paper is "normative legal research in the form of an inventory of local laws (customary law and customary rules that have been outlined in written form, such as decisions of customary functionaries, village regulations, etc.)".11 It is intended to find local laws in forest protection, both preventive and repressive, by imposing sanctions on perpetrators of forest destruction. The paper was written at "Universitas Kristen Indonesia from August to December 2020. The objects studied in this study were documents either in reports or regulations related to indigenous peoples' local wisdom, and the instrument used in this research is a document checklist. The data analysis technique used is the descriptive analysis technique. The data obtained, compiled in the manner described above, will be systematically compiled for subsequent content analysis qualitatively and finally written what should be done" .11

\section{Result and Discussion}

The concept of "forest in local law contains the philosophy of life that all kinds of living things in the forest, whether in the form of plants, animals, even supernatural beings, each have their function and role, which synergistically maintains order, goodness and

\footnotetext{
${ }^{16}$ Roy Ellen, "Nuaulu Ritual Regulation of Resources, Sasi and Forest Conservation in Eastern Indonesia," South East Asia Research 24, no. 1 (2016):5-22.
} 
balance of nature."17 Order goodness and balance of the universe concerning forest functions, such as not occurring floods, landslides, drought, maintaining soil fertility, and preventing the occurrence of other natural disasters that can disturb the tranquillity and peace of life of all community members, such as epidemics of infectious diseases and wild animal disturbances.

Forest, "part of the land in customary law communities, is jointly owned. Only the right to use it is individual. Forests as joint property rights have developed in every customary community in the Ambon island, familiar with the customary rights over the forest with all its inherent obligations. Meanwhile, management rights are granted based on the terms of a customary agreement that binds each member of the clan. The community uses forest resources to ensure the survival of individuals, groups and even clans. The legal relationship between customary law communities and their territorial forests creates rights that give the community, as a legal group, the right to collect forest products for the community's welfare. It is the original and primary right under local law covering all forests in indigenous and tribal peoples".18

Historically, forests that exist today come from a shared pool of resources where each individual and group can freely control and own them. However, human civilization has succeeded in formulating agreed-upon values and norms. It was creating corridors that limit forest use and control, as can be seen through all local legal instruments regulating the use and control of forest resources in each customary community, which gives birth to clan forest, or customary forest. ${ }^{19}$ Before "the promulgation of Law No. 5 of 1960 concerning Basic Agrarian Principles, it was estimated that forests in Indonesia were mostly common-pool resources that were not yet equipped with their management corridors. The government then controls the forest resources on behalf of the state, resulting in a transfer of tenure systems from common-pool resources and common property to state property rights. In its development, the government transferred the authority to control and manage forests to the private sector, and the nature of ownership became private property rights". 20

Forest protection effort is "an effort to prevent forest destruction "due to illegal forest occupation, forest use deviating from its function, and irresponsible forest exploitation, illegal mining, timber theft and illegal logging, livestock grazing and the result of fire, disturbance pests, and diseases and natural forces. Forest destruction itself is caused by rapid population growth, narrowing of agricultural land, accompanied by the socioeconomic conditions of communities around the forest, shifting cultivation, limited employment opportunities, and lack of public awareness of the importance of forest

${ }^{17}$ Ariyadi bin Ahmad, "Dayak Ngaju Forest Sustainability Sharia Maqashid Analysis," in ICIC 2020: Proceedings of the 1st International Conference on Islamic Civilization, ICIC 2020, 27th August 2020, Semarang, Indonesia (European Alliance for Innovation, 2020), 449.

${ }^{18}$ Rosemary Lyster, "REDD+, Transparency, Participation and Resource Rights: The Role of Law," Environmental Science \& Policy 14, no. 2 (2011):118-26.

19 James S Krueger, Legal Pluralism and Its Impact on Sustainability: Land, Forest, and Water Regulation Among Miraa Farmers in Kenya (The University of Wisconsin-Madison, 2017).

${ }^{20}$ Peter Cronkleton, Juan M Pulhin, and Sushil Saigal, "Co-Management in Community Forestry: How the Partial Devolution of Management Rights Creates Challenges for Forest Communities," Conservation and Society 10, no. 2 (2012): 91-102. 
functions and others".21 Local wisdom is "a value system or life behaviour of local people in interacting wisely with the environment in which they live. Etymologically, wisdom means a person's ability to use their mind to respond to an event, object or situation, while local shows the interaction space where the event or situation occurs. Thus, local wisdom is substantially the norm that applies in a society whose truth is believed to be and becomes a reference in daily actions and behaviour".22

Local wisdom is "all forms of knowledge, belief, understanding or insight, and customs or ethics that guide human behaviour in life in an ecological community. All forms of local wisdom are lived, practised, taught and passed on from generation to generation, forming patterns of human behaviour towards fellow humans, natural and occult". 3 Local wisdom is "the intelligence and management strategies of the universe in maintaining ecological balance that has been tested for centuries by various disasters and human obstacles and negligence. Local wisdom stops at ethics and comes to norms and actions and behaviour so that local wisdom can become like a religion that guides humans in behaving and acting, both in the context of everyday life and in determining other human civilization. Thus local wisdom is a traditional view and knowledge that becomes the reference in behaviour and has been practised from generation to generation to meet the needs and challenges in community life. Local wisdom functions and has meaning in society, preserving natural and human resources, customs and culture, and is beneficial for life"..24

The concept of forest protection in local law as living law emphasizes the principle of togetherness. Forest protection is the joint responsibility of customary law community members under the informal leadership of the head of the customary law community, the head of the tribe or the clan's head. Every indigenous community has the opinion that the destruction of the forest threatens the sustainability of human life. Forest "protection in local laws aims to prevent and limit the destruction of forests, and forest products, caused by human actions and defend the state's rights, community and individuals to forests". 25 The pattern of forest protection in local law is based on local legal rules in taboos and prohibitions. It is carried out through preventive measures in rule formation, counselling and supervision, and repressive forms of imposing customary sanctions - preventive implementation of forest protection in forming and implementing local forestry laws related to taboos or prohibitions.

"Law No. 32 of 2009 provides an understanding of local wisdom, namely the noble values that apply in the order of community life to, among others, protect and manage the environment in a sustainable manner, in this case, forests. Natural resources were

${ }^{21}$ E N Mwavu and E T F Witkowski, "Land-use and Cover Changes (1988-2002) around Budongo Forest Reserve, NW Uganda: Implications for Forest and Woodland Sustainability," Land Degradation \& Development 19, no. 6 (2008): 606-22.

${ }^{22}$ Cristina Bicchieri, Norms in the Wild: How to Diagnose, Measure, and Change Social Norms (Oxford University Press, 2016).

${ }^{23}$ Helmi Helmi, "Legal Protection to Manage Forest Resources Based on Local Wisdom," Journal of Critical Reviews 7, no. 09 (2020): 623-27.

${ }^{24}$ Hamid Darmadi, "Educational Management Based on Local Wisdom (Descriptive Analytical Studies of Culture of Local Wisdom in West Kalimantan)," Journal of Education, Teadhing and Learning 3, no. 1 (2018): 135-45.

${ }^{25}$ Tanya M Hayes, "Parks, People, and Forest Protection: An Institutional Assessment of the Effectiveness of Protected Areas," World Development 34, no. 12 (2006): 2064-75. 
created to be utilized by humans". ${ }^{26}$ However, there are rules and limitations in their utilization so that the balance of nature is maintained. These limitations include principles in conservation, which limit human behaviour to utilize natural resources wisely. The people in Lore Lindu do not recognize the term "conservation", even though the meaning of conservation is living in their activities as farmers. There are wisdom values in utilizing natural resources. These values align with the concept of "conservation" so that the natural resources they depend on for their survival will not run out and become extinct.

According to each sector, "awareness of protecting the forest environment is evident by including provisions for forest environmental protection and conservation of living natural resources and their ecosystems on land and sea in all laws and regulations governing natural resources". 27 Even the concept of development carried out by countries, including Indonesia as a country that is very dependent on natural resources, is directed so that in all its efforts to make use of it. It must pay attention to the balance of the forest environment and the preservation of its functions and capabilities so that in addition to providing maximum benefits for the welfare of the people, but it is valuable or felt by future generations. Nature conservation can be in the form of ocean conservation and land conservation. One of the mainland conservations is forest conservation which includes nature reserves, tourism forests, protected forests, and national parks. In conservation efforts, the function of forests and storing germplasm also function as raw material for medicine. The diversity of plant and animal species indicates the existence of a significant source of germplasm. Therefore, forest as a source of flora and fauna cultivation that has economic potential requires protection efforts. Forests also provide various types of medicine and food.

Humans and nature cannot be separated. This relationship is mutually beneficial and also mutually harmful. If humans take advantage of nature in good ways, nature will also provide good things. Still, if humans cause the damage, then humans will also suffer losses from the results that they do, so that humans become caliphs on earth as explained in the interpretation, that humans the human soul is often in a struggle to make good or bad choices. Humans, in their interactions with nature, are various cultures according to their respective traditions. ${ }^{28}$ In Maluku itself, there is a local wisdom culture known as "SASI". Sasi is a culture of environmental preservation, specific natural products within a period determined together in the Maluku community deliberation, applied in almost all of Maluku. Sasi contains an element of prohibition, and those who violate will be punished in the form of fines and punishments carried out by local communities in Maluku province. According to its history in Maluku, Sasi has existed since a long time ago, a joint commitment between traditional leaders, religious leaders, community leaders, and the community itself.

\footnotetext{
${ }^{26}$ Julia P G Jones, Mijasoa M Andriamarovololona, and Neal Hockley, "The Importance of Taboos and Social Norms to Conservation in Madagascar," Conservation Biology 22, no. 4 (2008): 976-86.

27 Vincent Itai Tanyanyiwa and Mercy Chikwanha, "The Role of Indigenous Knowledge Systems in the Management of Forest Resources in Mugabe Area, Masvingo, Zimbabwe," Journal of Sustainable Development in Africa 13, no. 3 (2011): 132-49.

${ }_{28}$ Shalom H Schwart, "An Overview of the Schwartz Theory of Basic Values," Online Readings in Psychology and Culture 2, no. 1 (2012):919-2307.
} 
The customary law of Sasi has been around for a long time. No accurate data or information has been found about when Sasi was enforced in this village, but from local legends or folklore. It is estimated that since the 1600s, Sasi has begun to be cultivated in Haruku (Maluku). "Sasi culture in nature conservation has become a tradition and culture in Maluku society, as a form of awareness that humans cannot live without nature. Sasi comes from hawaer balwarin, which is contained in article seven of Larwul Ngabal's customary law, which is the highest customary law in Key, Maluku". ${ }^{29}$ Sasi is a written or unwritten provision that prohibits the management of natural resources in the land (forest) and at sea for a certain period. 30

Sasi is "a community tradition with a substantive legal value, namely a temporary prohibition of not taking forest or marine products at a specific time. Sasi can have legal value because it has norms or rules related to ways, habits, behaviour, and customs that contain elements of norms and ethics".31 The number of islands in Maluku makes this area highly diverse, traditional culture in the form of customary rules and habits, especially in terms of natural resource management which already has conservation principles, namely: a) Respect that encourages harmony of human relations and natural surroundings; b) Exclusive ownership of an area or natural resource as common property, thus binding all citizens to safeguard and secure these natural resources from outsiders; c) A local knowledge system that gives the community the ability to solve problems they face in utilizing limited natural resources; d) Adaptability and use of simple technology that is efficient and efficient following local natural conditions; and e) A system of "allocation and enforcement of customary rules that can protect shared resources from overuse".

Sasi begins "with a traditional ceremony, then a prayer by traditional leaders, and ends with the installation of Sasi in three Janur Kuning and ai num wood embedded in the Sasi location. One example of the implementation of Sasi in Taar Village is the prohibition of anyone taking fish from Teluk Un. After one year, the implementation of the Sasi was opened (the Sasi was revoked) the result of the fish in Un Bay was abundant, because of the abundance, some of the fish was sold, and the money was used to build village infrastructure, including building a new church. Sasi is also often used to protect forests or is routinely used to ensure the sustainability of the clam population. Wherever Sasi is installed, indigenous people refrain from violating it. They believe that if it is violated, the disaster will immediately befall them".32

In addition, Ihamahu, for example, or in several other customary law areas in Maluku, in taking forest products, for instance, sago, to cut down one sago tree, cutting down the tree is obliged to replace it by planting ten sago saplings. Thus, the local wisdom of the people in Maluku is a real effort in supporting sustainable development. Sasi is

${ }^{29}$ Charles Zerner, “36. Through a Green Lens: The Construction of Customary Environmental Law and Community in Indonesia's Maluku Islands," in The Law and Society Reader II (New York University Press, 2014), 343-50.

${ }^{30}$ D Chalil et al., "Local Wisdom of Indigenous Society in Managing Their Customary Land: A Comparative Study on Tribes in Indonesia," in E3S Web of Conferences, vol. 52 (EDP Sciences, 2018), 23.

31 Majid Makki et al., "Thread-Level Resource Consumption Control of Tenant Custom Code in a Shared JVM for Multi-TenantSaaS," Future Generation Computer Systems 115 (2021): 351-64.

32 Vinit M Desai, "Rule Violations and Organizational Search: A Review and Extension," International Journal of Management Reviews 12, no. 2 (2010):184-200. 
made based on people's knowledge about the time or period when a resource can be harvested to not interfere with its life cycle, and the community gets good and maximum results. 33 The position of Sasi tends to be legal rather than traditional because the purpose of using Sasi is how people act wisely in harvesting and managing forest products. There are two essential terms in Sasi, namely Buka Sasi and Tutup Sasi. Buka Sasi is when people are allowed to harvest or take a resource that is being Sasi. Meanwhile, Sasi closure is when the help is prohibited from being gathered and protected again by Sasi law.

The Sasi will be opened according to a predetermined time. The Sasi begins with a traditional ceremony attended by the head of the kewang, the Saniri country and the village community. The opening of the Sasi will be decided in a meeting attended by the kewang, kings, Saniri Country and religious leaders. This meeting was held when the time to open the Sasi was approaching. The opening of the Sasi was carried out officially with direct notification by the kewang institution through one of the Marinyo by shouting while going around the village so that the public would know it. The opening of the Sasi was carried out based on two reasons: first, there was a market demand or buyer for economic needs. Second, for the daily consumption needs of the community and social needs such as the construction or repair of mosques or churches, village facilities and the celebration of religious holidays. ${ }^{34}$ One area affected by the Sasi law is a land area (forest), either individually or jointly owned. Forest Sasi regulates all exploitation activities (harvesting) of all land resources (forest). The description of the forest Sasi is as follows:

Planning - The auction is the initial stage of forest Sasi activities, where the highest bidder will win the auction and form a management institution (kewang). This institution will work following the mutual agreement determined when the auction activity is over. ${ }^{35} 36$ Matters agreed upon during the auction are a) forest Sasi area/location, b) Sasi validity period, c) forest products affected by Sasi, and d) sanctions. Efforts to prevent violations committed during the Sasi period or at the time of closing the Sasi cause the perpetrators to be sanctioned. Sanctions in the Sasi law vary from country to country in Maluku, but generally, they are subject to sanctions in the form of fines. The fine depends on each community member's type and the number of natural resources taken (stolen). Apart from sanctions in the form of objects, there is also corporal punishment (whipping) for children. Even sentence is being paraded around the village with thieves' shouts (if repeated three times). Of the various violations that have occurred, it turns out that those with high intensity are those committed by children, such as taking young nutmegs and shedding nutmeg flowers

33 Nurdina Prasetyo, Anna Carr, and Sebastian Filep, "Indigenous Knowledge in Marine Ecotourism Development: The Case of Sasi Laut, Misool, Indonesia," Tourism Planning \& Development 17, no. 1 (2020): 46-61.

${ }^{34} \mathrm{R}$ H Haulussy, Idris R Najamuddin, and ADMP Agustang, "The Sustainability of the Sasi Lola Tradition and Customary Law (Case Study in Masawoy Maluku, Indonesia)," Intl J Sci Technol Res 9, no. 2 (2020): 5193-95.

${ }^{35}$ Ivonne Raystika Gretha Kaya, Johannes Hutabarat, and Azis Nur Bambang, “'Sasi': A New Path to Sustain Seaweed Farming From Up-Stream to Down-Stream in Kotania Bay, Molucass," International Journal of Social Ecology and Sustainable Development (IJSESD) 9, no. 2 (2018): 28-36.

${ }^{36}$ Trinovianto G R Hallatu, I D Palittin, and M Chairul Basrun Umanailo, "Culture and Religion in Sasi Tradition," in Proceedings of the International Conference on Industrial Engineering and Operations Management, 2019, 984-90. 
while playing so that they are subject to sanctions in the form of whipping them and additional punishment from people. It is done because of the shame of their parents hoping that somebody will not repeat the child action.

Implementation - After the auction is completed, the kewang starts working, following what was ordered by kewang. These jobs can be described as follows: a) Installation of Sasi signs (Close Sasi), b) Making guard posts, c) Harvesting (Open Sasi), d) Maintenance. Supervision - Kewang is a management institution tasked with supervising both in the forest, guard posts and settlements of all resources in the forest during a predetermined period at the auction, both at the closing opening of the Sasi. It is intended to prevent the destruction and theft of all forest resources. This supervisory activity is called Maajaga. Management of products - Management of forest products referred to is the results obtained by the kewang. After the kewang receives $10 \%$ of the community harvest, the results will be collected at the kewangs' house to be counted and processed. ${ }^{37}$ It is done for transparency between the head of the kewang and its members, so there is no mutual suspicion. Marketing - After all the results have been collected in large numbers, the head of the Kewang will give its members to check the market prices to determine the best steps in marketing to get maximum profit. Marketing is usually carried out in the city of Ambon or directly taken out of Ambon island to be marketed post-COVID-19.

The application of Sasi law, which is aimed at humans, actually has relevance to preventing people's traffic in certain areas so that massive and large-scale transmission does not occur. For example, by making Sasi signs in certain areas in a village or subdistrict, people will not automatically cross these areas to prevent people's movement from one place to another. Although the Sasi law is not written, it contains certain sanctions. Sanctions in sasi law are not as severe as positive or state law, but at least they can provide a deterrent effect from the customary side. So indigenous peoples who know and understand and obey customs and customary law will obey customary law, namely Sasi law.

Applying the Sasi law with the interaction of the kewang institution or other government institutions such as the King and Saniri is essential and decisive to protect the community and break the spread of COVID-19. Law enforcement needs some backing to use to be meaningful or valuable. The Kewang Institution or Forest Police must have the ability and power under Sasi law. Kewang must know and understand the nature or meaning of the norms in the Sasi law. It means that Sasi law must be expanded in its essence and scope of application so that it is not only aimed at natural resources, but Sasi law also applies to the movement of specific people or humans who will enter certain areas. So those places are declared as protected places in Sasi. Then people are not allowed to pass through these places to prevent the transmission of COVID-19.

Preventing the spread of COVID-19 is very important, realizing that many people impact their health and their food security. Alternatives to survive during the COVID19 pandemic to utilize forest products are something that can be avoided. Still, it is also essential that systematic, integrated efforts are carried out for environmental functions

${ }^{37}$ Syahibul K Hamid et al., "The Support of MPA (Marine Protected Area) in Coral Triangle Area: Evidence from Kei Islands, Indonesia," in IOP Conference Series: Earth and Environmental Science, vol. 89 (IOP Publishing, 2017), 12025. 
and prevent damage to the planned environment, utilization, control, maintenance, supervision, and law enforcement.

\section{Conclusion}

Sasi is a form of temporary prohibition for the community to refrain from exploiting natural resources inland areas, both private property (non-ulayat) and collective property (ulayat rights) and marine areas that are owned or controlled by the village head. All those who have to secure the implementation of all Sasi activities impose sanctions on offenders, check the boundaries of the affected areas and put up signs of Sasi. One of the Sasi law areas is the land area (forest) wherein forest management, and there are several stages, namely planning, implementation (maintenance, harvesting, planting), supervision, product management, and marketing. That traditional Sasi wisdom has values and norms to protect forests, water sources, annual plants, and food plants. With the concept and understanding of how environmental managements with various customary rules to obtain benefits and maintain the kinship value of area units that already have an identity and must continuously be maintained in the aftermath of the COVID-19 pandemic.

\section{Acknowledgments}

We do say thank you to the Rector of Universitas Kristen Indonesia for the supports and also fund to do the research and publication.

\section{References}

Book

Bicchieri, Cristina. Norms in the Wild: How to Diagnose, Measure, and Change Social Norms. Oxford University Press, 2016.

Flint, R Warren. Practice of Sustainable Community Development: A Participatory Framework for Change. Springer, 2012.

Jørgensen, Sven Erik, Brian D Fath, Søren Nors Nielsen, Federico M Pulselli, Daniel A Fiscus, and Simone Bastianoni. Flourishing Within Limits to Growth: Following Nature's Way. Routledge, 2015.

Krueger, James S. Legal Pluralism and Its Impact on Sustainability: Land, Forest, and Water Regulation Among Miraa Farmers in Kenya. The University of Wisconsin-Madison, 2017.

Rangkuti, Siti Sundari. Hukum Lingkungan $\mathcal{E}$ Kebijaksanaan Ling Nasional Ed 4. Airlangga University Press, 2020.

Schaefer, Jame. Theological Foundations for Environmental Ethics: Reconstructing Patristic and Medieval Concepts. Georgetown University Press, 2009.

\section{Journal}

Ahmad, Ariyadi bin. "Dayak Ngaju Forest Sustainability Sharia Maqashid Analysis." In ICIC 2020: Proceedings of the 1st International Conference on Islamic Civilization, ICIC 2020, 27th August 2020, Semarang, Indonesia, 449. European Alliance for Innovation, 2020.

Balbus, John M, Alistair B A Boxall, Richard A Fenske, Thomas E McKone, and Lauren Zeise. "Implications of Global Climate Change for the Assessment and 
Management of Human Health Risks of Chemicals in the Natural Environment." Environmental Toxicology and Chemistry 32, no. 1 (2013): 62-78.

Boyle, Alan. "Human Rights or Environmental Rights? A Reassessment." Fordham Environmental Law Review, 2007, 471-511.

Chalil, D, S F Sidique, R Barus, A H I Abdul Hadi, M Khaliqi, and M I Fatoni. "Local Wisdom of Indigenous Society in Managing Their Customary Land: A Comparative Study on Tribes in Indonesia." In E3S Web of Conferences, 52:23. EDP Sciences, 2018.

Cronkleton, Peter, David Barton Bray, and Gabriel Medina. "Community Forest Management and the Emergence of Multi-Scale Governance Institutions: Lessons for REDD+ Development from Mexico, Brazil and Bolivia." Forests 2, no. 2 (2011): 451-73.

Cronkleton, Peter, Juan M Pulhin, and Sushil Saigal. “Co-Management in Community Forestry: How the Partial Devolution of Management Rights Creates Challenges for Forest Communities." Conservation and Society 10, no. 2 (2012): 91-102.

Darmadi, Hamid. "Educational Management Based on Local Wisdom (Descriptive Analytical Studies of Culture of Local Wisdom in West Kalimantan)." Journal of Education, Teaching and Learning 3, no. 1 (2018): 135-45.

Desai, Vinit M. "Rule Violations and Organizational Search: A Review and Extension." International Journal of Management Reviews 12, no. 2 (2010): 184-200.

Ellen, Roy. "Nuaulu Ritual Regulation of Resources, Sasi and Forest Conservation in Eastern Indonesia." South East Asia Research 24, no. 1 (2016): 5-22.

Hallatu, Trinovianto G R, I D Palittin, and M Chairul Basrun Umanailo. "Culture and Religion in Sasi Tradition." In Proceedings of the International Conference on Industrial Engineering and Operations Management, 984-90, 2019.

Hamid, Syahibul K, Wellem A Teniwut, Roberto M K Teniwut, Meyske A Rahantoknam, Cawalinya L Hasyim, and Marselus Hungan. "The Support of MPA (Marine Protected Area) in Coral Triangle Area: Evidence from Kei Islands, Indonesia." In IOP Conference Series: Earth and Environmental Science, 89:12025. IOP Publishing, 2017.

Haulussy, R H, Idris R Najamuddin, and ADMP Agustang. "The Sustainability of the Sasi Lola Tradition and Customary Law (Case Study in Masawoy Maluku, Indonesia)." Intl J Sci Technol Res 9, no. 2 (2020): 5193-95.

Hayes, Tanya M. "Parks, People, and Forest Protection: An Institutional Assessment of the Effectiveness of Protected Areas." World Development 34, no. 12 (2006): 206475.

Hayes, Tanya, and Elinor Ostrom. "Conserving the World's Forests: Are Protected Areas the Only Way." Ind. L. Rev. 38 (2005): 595.

Helmi, Helmi. "Legal Protection to Manage Forest Resources Based on Local Wisdom." Journal of Critical Reviews 7, no. 09 (2020): 623-27.

Hidayat, Herman, Herry Yogaswara, Tuti Herawati, Patricia Blazey, Stephen Wyatt, and Richard Howitt. "Forests, Law and Customary Rights in Indonesia: Implications of a Decision of the Indonesian Constitutional Court in 2012" Asia Pacific Viewpoint 59, no. 3 (2018): 293-308.

Jones, Julia P G, Mijasoa M Andriamarovololona, and Neal Hockley. "The Importance of Taboos and Social Norms to Conservation in Madagascar." Conservation Biology 22, no. 4 (2008): 976-86.

Kaya, Ivonne Raystika Gretha, Johannes Hutabarat, and Azis Nur Bambang. "'Sasi': A New Path to Sustain Seaweed Farming From Up-Stream to Down-Stream in 
Kotania Bay, Molucass." International Journal of Social Ecology and Sustainable Development (IJSESD) 9, no. 2 (2018): 28-36.

Kuuluvainen, Timo. "Forest Management and Biodiversity Conservation Based on Natural Ecosystem Dynamics in Northern Europe: The Complexity Challenge." Ambio, 2009, 309-15.

Lyster, Rosemary. "REDD+, Transparency, Participation and Resource Rights: The Role of Law." Environmental Science \& Policy 14, no. 2 (2011): 118-26.

Makki, Majid, Dimitri Van Landuyt, Bert Lagaisse, and Wouter Joosen. "Thread-Level Resource Consumption Control of Tenant Custom Code in a Shared JVM for Multi-Tenant SaaS." Future Generation Computer Systems 115 (2021): 351-64.

Muawanah, Umi, Gellwynn Yusuf, Luky Adrianto, Jimy Kalther, Robert Pomeroy, Habibi Abdullah, and Toni Ruchimat. "Review of National Laws and Regulation in Indonesia in Relation to an Ecosystem Approach to Fisheries Management." Marine Policy 91 (2018): 150-60.

Mwavu, E N, and E T F Witkowski. "Land-use and Cover Changes (1988-2002) around Budongo Forest Reserve, NW Uganda: Implications for Forest and Woodland Sustainability." Land Degradation \& Development 19, no. 6 (2008): 606-22.

Prasetyo, Nurdina, Anna Carr, and Sebastian Filep. "Indigenous Knowledge in Marine Ecotourism Development: The Case of Sasi Laut, Misool, Indonesia." Tourism Planning \& Development 17, no. 1 (2020): 46-61.

Schwartz, Shalom H. "An Overview of the Schwartz Theory of Basic Values." Online Readings in Psychology and Culture 2, no. 1 (2012): 919-2307.

Sunderlin, William D, Arild Angelsen, Brian Belcher, Paul Burgers, Robert Nasi, Levania Santoso, and Sven Wunder. "Livelihoods, Forests, and Conservation in Developing Countries: An Overview." World Development 33, no. 9 (2005): 13831402.

Tanyanyiwa, Vincent Itai, and Mercy Chikwanha. "The Role of Indigenous Knowledge Systems in the Management of Forest Resources in Mugabe Area, Masvingo, Zimbabwe." Journal of Sustainable Development in Africa 13, no. 3 (2011): 132-49.

Tehupeiory, Aarce. "SASI-BASED PROTECTION FOREST STRATEGY IN MALUKU (AMBON)." International Journal of Research-GRANTHAALAYAH 9, no. 3 (2021): 221-28.

Wiens, John A. "Landscape Ecology as a Foundation for Sustainable Conservation." Landscape Ecology 24, no. 8 (2009): 1053-65.

Wiessner, Siegfried. "Indigenous Sovereignty: A Reassessment in Light of the UN Declaration on the Rights of Indigenous People." Vand. J. Transnat'l L. 41 (2008): 1141.

Zerner, Charles. "36. Through a Green Lens: The Construction of Customary Environmental Law and Community in Indonesia's Maluku Islands." In The Law and Society Reader II, 343-50. New York University Press, 2014. 